\title{
AN EVALUATION OF THE VAGINAL SMEAR TECHNIQUE FOR DETECTING THE OCCURRENCE OF OVULATION IN THE EWE
}

\author{
M. J. DUCKER AND J. S. BOYD \\ Departments of Animal Husbandry and Veterinary Anatomy, \\ Glasgow University Veterinary School, Bearsden, Glasgow
}

(Received 29th May 1974)

The vaginal smear contents of the ewe have been shown to change during the course of the oestrous cycle (Grant, 1934). The uniform appearance in the vaginal smear of cheesy masses of cornified epithelial cells first occurred within 3 days after the onset of oestrus in oestrous cycles lasting 16 to 20 days (Radford \& Watson, 1955). Radford \& Watson (1955) suggested that the massive desquamation and cornification of the vaginal epithelium was related to the occurrence of ovulation, since ovulation usually occurred 1 to 2 days after the commencement of oestrus. Similar changes in the vaginal smear contents of ewes have been observed during anoestrus (Grant, 1934) and may be indicative of silent ovulations (Cole \& Miller, 1935).

The aim of this experiment was to provide conclusive evidence on the use of the vaginal smear technique for detecting the occurrence of ovulation in ewes during anoestrus and the breeding season.

Twenty-six Greyface ewes (Border Leicester $\delta \times$ Scottish Blackface + ) various ages were used for the experiment. The mean duration of the breeding season for these ewes was from 22nd September 1971 to 18th February 1972 (Ducker \& Boyd, 1974). Vaginal smears were taken every Monday, Wednesday and Friday from 23rd June until 18th October 1971 and from 14th February until 20th June 1972. The intention was to take vaginal smears throughout the periods of anoestrus before and after the breeding season and also during a limited period of the breeding season.

The collection of the vaginal smears followed the procedure described by Radford \& Watson (1955). The slides of the vaginal samples were stained with Delafield's haematoxylin, washed with water and stained with eosin $(1 \%$ in $95 \%$ alcohol). The slides were washed, dried and examined under $\times 250$ magnification for the presence of small or large round epithelial cells, leucocytes and cornified epithelial cells. The ovaries of all the ewes were examined on ten occasions between July 1971 and June 1972 using a peritoneoscope (Ducker \& Boyd, 1974). The equipment and the method of operation have been fully described by Boyd \& Ducker (1973).

Data relating to the occurrence and accuracy of the various indications of ovulation have been analysed by $\chi^{2}$ analysis. Data relating to the time of 
occurrence of the indications of ovulation have been analysed by means of $t$ tests for paired comparisons.

Our categories of 'indication of ovulation' were devised to interpret the vaginal smear data. A definite indication of ovulation was provided by a series of vaginal smears without cornified cells (negative vaginal smear) followed by a series of smears containing a large proportion of cornified cells (positive smears). A weak indication of ovulation was provided by a similar change from negative to positive vaginal smears but the proportion of cornified cells present in the possitive smears was much lower. A possible indication of ovulation was considered when there was a definite change in the proportion of cornified cells and the presence of the other cell types although all the smears contained cornified cells. Positive and negative vaginal smears occasionally occurred in a random manner. These occurrences were classified as indefinite indications of ovulation and were considered separately from the other three types.

Table 1. The occurrence of the various indications of ovulation in ewes

\begin{tabular}{|c|c|c|c|c|}
\hline $\begin{array}{l}\text { Type of } \\
\text { indication } \\
\text { of ovulation }\end{array}$ & Total observed & No. confirmed & No. correct & $\%$ Correct \\
\hline $\begin{array}{c}\text { ANOESTRUs } \\
\text { Weak } \\
\text { Definite } \\
\text { Possible } \\
\text { Total }\end{array}$ & $\begin{array}{r}30 \\
76 \\
5 \\
111\end{array}$ & $\begin{array}{r}19 \\
46 \\
3 \\
68\end{array}$ & $\begin{array}{r}2 \\
21 \\
1 \\
24\end{array}$ & $\begin{array}{l}11^{\mathrm{a}, \mathrm{e}, \mathrm{f}} \\
46^{\mathrm{b}, \mathrm{e}} \\
33 \\
35^{\mathrm{c}, \mathrm{f}}\end{array}$ \\
\hline Indefinite & 16 & 11 & 3 & $27^{d}$ \\
\hline $\begin{array}{l}\text { LIMITED BREEDI } \\
\text { SEASON } \\
\text { Weak } \\
\text { Definite } \\
\text { Possible } \\
\text { Total }\end{array}$ & $\begin{array}{r}7 \\
47 \\
1 \\
55\end{array}$ & $\begin{array}{r}4 \\
21 \\
0 \\
25\end{array}$ & $\begin{array}{r}4 \\
21 \\
25\end{array}$ & $\begin{array}{l}100^{\mathrm{a}} \\
100^{\mathrm{b}} \\
\frac{-}{100^{\mathrm{c}}}\end{array}$ \\
\hline Indefinite & 5 & 5 & 5 & $100^{\mathrm{d}}$ \\
\hline
\end{tabular}

Figures with the same superscript are significantly different: $a, b, c P<0.001$; d.e $P<0.01 ;$ ' $P<0.05$.

The occurrence of the various indications of ovulation are shown in Table 1 . Since only a maximum of ten visual inspections of the ovaries could be performed for each ewe, it was not possible to confirm all the indications of ovulation which were recorded throughout the experiment. By operating on the dates described, both a large $(56 \%)$ and representative sample of the indications of ovulation were confirmed.

The results of the present experiment showed conclusively that the changes in the various cell types present in the vaginal smears of the ewes during anoestrus were unreliable for detecting the occurrence of ovulation; only $35 \%$ of the indications of ovulation were correct. Weak indications of ovulation were extremely inaccurate during anoestrus (11\% correct) and even definite 
indications were only $46 \%$ correct. Of the correct indications, $87 \%$ were definite and $13 \%$ were weak or possible $(P<0.01)$. The definite indications also occurred nearer to the breeding season than did the weak indications $(38.8 \pm 3.0$ and $50.8 \pm 5.3$ days, respectively; $P<0.05)$. Ovulation ceased to occur as anoestrus progressed. Mainly medium and large follicles were present in the ovaries (Ducker \& Boyd, 1974), and, in the absence of ovulation, the follicles appeared to be capable of maintaining a cyclical pattern of oestrogen secretion which produced changes in the vaginal smears every 14 to 20 days which were similar to those observed when ovulation was occurring (Robinson \& Moore, 1956). On the occasions when incorrect indications were found, the ovaries of the ewes usually $(80 \%)$ contained medium and large follicles and rarely only small follicles. Towards the middle of anoestrus, the proportion of small follicles present in the ovaries increased and most vaginal smears were negative.

Apart from the incorrect indications of ovulation provided by the changes in vaginal smears during anoestrus, three ovulations occurred during periods of indefinite indications and, on at least three other occasions, ovulation occurred during periods of continually negative vaginal smears.

During the breeding season, fifty-five indications of ovulation were evident from the vaginal smears taken during the limited period described. All these indications were accompanied by overt oestrus; $13 \%$ were weak and $85 \%$ were definite compared to $27 \%$ and $68 \%$, respectively, during the anoestrous period $(P<0.05)$. Changes in the vaginal smears were significantly more accurate for detecting the occurrence of ovulation during the breeding season $(P<0.001)$, although ovulations still occurred which were not detected by the appropriate changes in the vaginal smears. Five ovulations occurred when vaginal smears were continually negative and five occurred when the indications of ovulation were only indefinite (Table 1).

It is concluded that sequential changes in the cell types present in the vaginal smears are unreliable as the sole means of detecting ovulation in ewes.

\section{REFERENCES}

Boyd, J. S. \& Ducker, M. J. (1973) A method of examining the cyclic changes occurring in the sheep ovary using endoscopy. Vet. Rec. 93, 40.

Cole, H. H. \& Miller, R. F. (1935) The changes in the reproductive organs of the ewe with some data on their control. Am. F. Anat. 57, 39.

DuCKER, M. J. \& BoYD, J. S. (1974) The effect of daylength and nutrition on the oestrous and ovulatory activity of Greyface ewes. Anim. Prod. 18, 159.

Grant, R. (1934) Studies on the physiology of reproduction in the ewe. Trans. R. Soc. Edinb. 58, 1.

RADFORD, H. M. \& WATSON, R. H. (1955) Changes in the vaginal contents of the Merino ewe throughout the year. Aust. F. agric. Res. 6, 431.

Robinson, T.J. \& MOoRE, N. W. (1956) The interaction of oestrogen and progesterone on the vaginal cycle of the ewe. $\mathcal{F}$. Endocr. 14, 97. 